\title{
Research on Curriculum Reform of Introduction to Environmental Protection-Taking Shandong Vocational College of Light Industry as an Example
}

\author{
Wanyi Shen \\ Shandong Vocational College of light Industry, Zibo, Shandong, 255300, China \\ shenwanyi@126.com
}

Keywords: introduction to environmental protection; curriculum reform.

\begin{abstract}
As a course in the study field of chemical technology specialty in higher vocational colleges, Introduction to environmental protection occupies a very important position in the course of this specialty. In view of the application and exploratory characteristics of higher vocational education, this paper explores and studies the curriculum reform of "introduction to environmental protection" from the aspects of curriculum reform concept, teaching content, teaching mode and assessment mode.
\end{abstract}

\section{Introduction}

Environmental problems have always been one of the problems that plagued the development of chemical enterprises. Especially in recent years, the state attaches more and more importance to environmental problems. Chemical enterprises must have environmental protection functions and the ability to deal with pollutants in their production. This also requires enterprises to have special environmental protection personnel. At the same time, enterprises also hope that employees of chemical industry have a certain sense of environmental protection. Therefore, the students of chemical engineering major in higher vocational colleges need to pay attention to the cultivation of environmental protection consciousness in school, especially in the teaching process of "Introduction to Environmental Protection". They should be student-centered and pay attention to the cultivation of environmental protection consciousness in combination with the actual production cases of enterprises, so as to make students understand the importance of environmental protection, change the traditional teaching mode and carry out it purposefully. Curriculum reform.

\section{Basic information of course}

The course system is composed of three fields: quality and basic learning, professional learning and professional development. The course "Introduction to Environmental Protection" is a professional learning course. It is offered in the second semester of the second year of college.

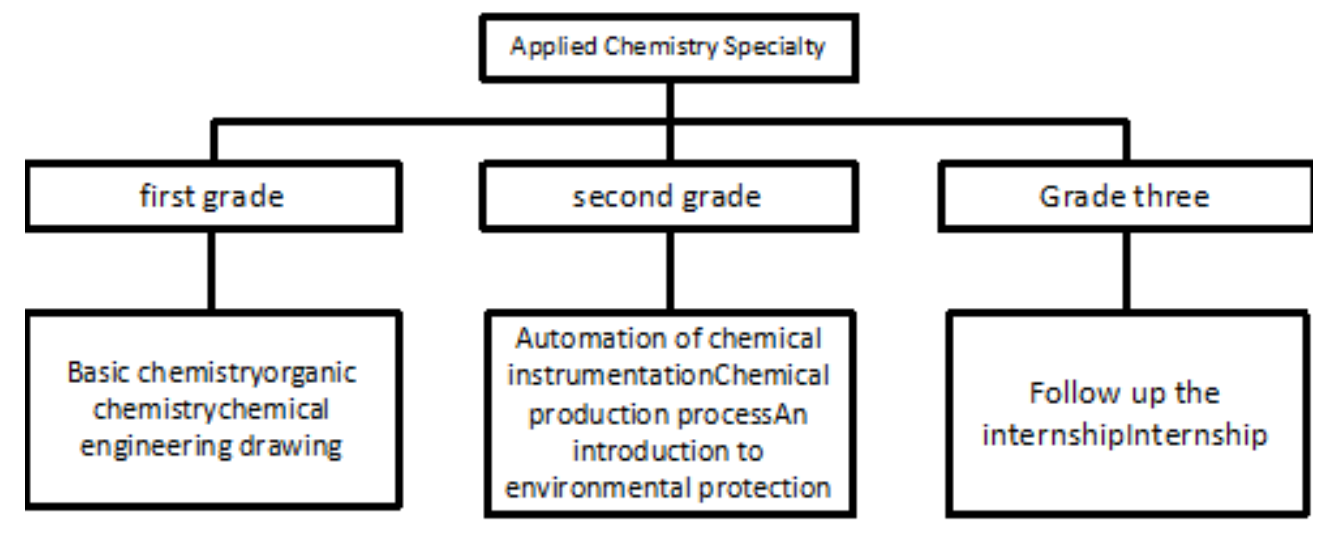

Fig. 1 location of introduction to environmental protection in the curriculum system 
A total of 2 credits, 2 hours / weeks, totaling 36 hours. The course of introduction to environmental protection in the course system of Applied Chemical Engineering in our university is like the following figure 1 .

\section{Ideas and objectives of curriculum reform}

\subsection{The concept of curriculum reform}

Taking the possible environmental pollution factors in chemical industry as the breakthrough point, taking the relevant environmental protection treatment methods involved in chemical production as the main line of teaching, designing the teaching situation with accident cases, focusing on vocational ability training, and adopting various teaching methods, students can master safety knowledge.

Taking the real waste produced by the school-enterprise cooperative enterprise as an example, the waste water, waste gas and waste residue produced by Shandong Hongxin Chemical Co., Ltd. are taken as an example. Through visiting, technological design, video learning and other means, the authentic treatment mode of the enterprise is realized, the importance of the enterprise to environmental protection is realized, and the theory and practice are combined to realize the environmental protection. Security awareness goes through the whole process of student learning.

\subsection{Objectives of curriculum reform}

Its main task is to improve students' awareness of chemical environmental protection, increase students' knowledge of chemical environmental protection, and cultivate students' awareness and ability of attaching importance to environmental protection in their practice and future work. Through teaching, on the one hand, students should broaden and deepen the basic knowledge of chemical environmental protection. While mastering chemical professional knowledge, students should master the basic knowledge of environmental protection, and combine the two to understand the concept of chemical environmental protection without division. On the other hand, students can consciously put pollution control and pollution emission minimization in the future production, management and other work in an important position. Students should grasp the production skills at the same time, recognize the current situation of no environmental protection but production, clarify the importance of environmental protection, form environmental awareness, adapt to the new situation of environmental protection. Please.

\section{Reform of teaching mode}

\subsection{Using modern information technology teaching methods}

Make full use of modern information technology teaching means, build a quality resource sharing course, use blue clouds to teach, improve the enthusiasm of students to learn. Making full use of the excellent resources in the national teaching resource database and combining with their own characteristics, the students can learn the course design, teaching plan, courseware, video, case and so on.

Mainly from the following four aspects of the use of modern information technology teaching means for reform: first, the introduction of synchronous video teaching means, so that teachers can really play back, facilitate students to review and consolidate knowledge learning in a timely manner; second, school-enterprise cooperation to build a "school-enterprise synchronization platform" with Shandong Hongxin Chemical Co., Ltd. Build a learning center platform, set up a video main venue in school, deploy remote video terminals in the company, the enterprise scene can be timely presented to the classroom, for students learning and production process real-time interaction of remote training and teaching; third, carry out the construction of digital teaching resources; fourth, double-subject teaching, flipped classroom teaching and so on. The application of informationalized teaching method to teaching design. 


\subsection{Practical case teaching}

We should make full use of the Internet to collect real cases, especially the actual cases in this region. Combine the content of courses with the cases of surrounding enterprises, and analyze them while learning. Employ enterprise experts or on-the-spot case analysis to make practical comments on students'cases, and fully mobilize students' interest and enthusiasm in learning.

Mainly from the following aspects: First, the Shandong Weifang Runfeng Chemical Co., Ltd., Zibo Yongda Chemical Co., Ltd. and other old factory environmental protection problems were analyzed, and control measures were proposed. Use real cases to stimulate students' interest in learning. The second is to employ relevant enterprise environmental experts to comment on the case analysis of students, from the perspective of enterprises, more realistic.

\subsection{Relying on school enterprise cooperation}

Relying on the school-enterprise cooperative enterprises, students are organized to visit and practice chemical enterprises, so that students can go deep into the enterprise how to carry out environmental protection, more close to reality, and cultivate students' awareness of environmental protection. Make full use of students' internship opportunities to enterprises to understand the various environmental protection situation of enterprises, the adopted technology, methods and problems, comparative analysis, the formation of their own views of the report.

\section{Reform of assessment methods}

\subsection{Assessment ideas}

The traditional assessment method is the final examination paper, but the "Introduction to Environmental Protection" course is a high demand for ability analysis course, the purpose is to cultivate environmental awareness, such assessment can not reflect the actual ability of students, nor can meet the needs of enterprises. Therefore, in the process of teaching assessment, students will be the main body, focusing on the assessment of students' ability to analyze and solve problems, giving special encouragement to innovative students in learning and application, and comprehensively evaluating students' ability. Course assessment is based on the learning process assessment, focusing on the ability of students to complete learning tasks, assessment content and weight as follows: Table 1

Table 1 Assessment contents and weights of teaching evaluation

\begin{tabular}{|c|c|c|c|}
\hline \multicolumn{2}{|c|}{ Examination content } & weight coefficient & subtotal \\
\hline \multirow{2}{*}{ peacetime } & Attendance & 10 & \multirow{2}{*}{30} \\
\cline { 2 - 3 } & $\begin{array}{c}\text { Comprehensive } \\
\text { performance }\end{array}$ & 10 & \\
\cline { 2 - 3 } & Operation situation & 10 & 30 \\
\hline \multicolumn{2}{|c|}{ Periodic investigation } & 30 & 40 \\
\hline \multicolumn{2}{|c|}{ Final exam } & 40 & \\
\hline
\end{tabular}

\subsection{The main content and weight of teaching evaluation}

The average score of the examination is $60 \%$, and the process assessment is more important. Especially the periodic assessment, including the knowledge of stages, the depth of analysis of enterprise cases, feasibility and other indicators, in order to refine the assessment, the assessment table is drawn up as follows: 
Table 2 Stage assessment form

\begin{tabular}{|c|c|c|c|c|}
\hline projectName & & & $\begin{array}{c}\text { Project } \\
\text { attributes }\end{array}$ & \\
\hline Group number & Name & & $\begin{array}{l}\text { School } \\
\text { number }\end{array}$ & \\
\hline \multicolumn{2}{|r|}{ Evaluation content } & $\begin{array}{l}\text { Student self } \\
\text { evaluation } \\
(20 \%)\end{array}$ & $\begin{array}{l}\text { panel } \\
\text { evaluation } \\
\text { (30\%) }\end{array}$ & $\begin{array}{l}\text { teacher } \\
\text { evaluation } \\
\text { (50\%) }\end{array}$ \\
\hline \multicolumn{2}{|c|}{$\begin{array}{l}\text { 1. is learning objectives clear? Whether the learning } \\
\text { attitude is proactive and can complete the tasks assigned } \\
\text { by teachers in time ( } 5 \text { points). }\end{array}$} & & & \\
\hline \multicolumn{2}{|c|}{$\begin{array}{l}\text { 2. whether the learning process is on the rise and making } \\
\text { progress ( } 5 \text { points) }\end{array}$} & & & \\
\hline \multicolumn{2}{|c|}{$\begin{array}{l}\text { 3. Whether the process of inquiry activities is recorded } \\
\text { completely, and whether the relevant learning information } \\
\text { and materials collected are perfect (10 points) }\end{array}$} & & & \\
\hline \multicolumn{2}{|c|}{$\begin{array}{l}\text { 4. Whether the project can be reasonably analyzed } \\
\text { according to the learning materials, and the feasibility } \\
\text { analysis of the proposed scheme can be carried out. What } \\
\text { is the quality of the work plan worked out ( } 10 \text { points) }\end{array}$} & & & \\
\hline \multicolumn{2}{|c|}{$\begin{array}{l}\text { 5. Whether actively participate in various discussions and } \\
\text { speeches, and can clearly express their views and ideas, } \\
\text { timely problem solving (10 points) }\end{array}$} & & & \\
\hline \multicolumn{2}{|c|}{$\begin{array}{l}\text { 6. Whether the experimental project can be completed } \\
\text { independently or cooperatively according to the } \\
\text { experimental scheme. How about the performance of the } \\
\text { operation on the project day ( } 20 \text { points) }\end{array}$} & & & \\
\hline \multicolumn{2}{|c|}{$\begin{array}{l}\text { 7. Whether the original records, implementation reports, } \\
\text { inspection and analysis reports in the process of project } \\
\text { implementation meet the requirements ( } 10 \text { points) }\end{array}$} & & & \\
\hline \multicolumn{2}{|c|}{$\begin{array}{l}\text { 8., can we think about the problems in the process of } \\
\text { experiment and use existing knowledge to solve them? } \\
\text { And know the deficiency of your knowledge ( } 10 \text { points). }\end{array}$} & & & \\
\hline \multicolumn{2}{|c|}{$\begin{array}{l}\text { 9. Achieving the required competency goals through } \\
\text { project training. Establishing overall professional } \\
\text { qualities such as safety, environmental awareness and } \\
\text { teamwork spirit ( } 5 \text { points) }\end{array}$} & & & \\
\hline \multicolumn{5}{|c|}{$\begin{array}{l}\text { 10. the orderliness, regularity and beauty of archiving } \\
\text { documents ( } 5 \text { points) }\end{array}$} \\
\hline \multicolumn{5}{|c|}{$\begin{array}{l}\text { 11., can we conscientiously sum up and correctly evaluate } \\
\text { the completion of the project ( } 5 \text { points)? }\end{array}$} \\
\hline \multicolumn{5}{|c|}{$\begin{array}{l}\text { 12. whether each task is timely and conscientiously } \\
\text { completed ( } 5 \text { points) }\end{array}$} \\
\hline \multicolumn{5}{|c|}{\begin{tabular}{c|l}
$\begin{array}{c}\text { General } \\
\text { comment }\end{array}$ & \\
\end{tabular}} \\
\hline \multicolumn{5}{|l|}{ Advantage } \\
\hline \multicolumn{5}{|l|}{ insufficient } \\
\hline \multicolumn{5}{|l|}{$\begin{array}{l}\text { Improvement } \\
\text { Opinion }\end{array}$} \\
\hline $\begin{array}{l}\text { Completion } \\
\text { date }\end{array}$ & & & & \\
\hline
\end{tabular}




\section{Effect analysis of curriculum reform}

Traditional teaching is the teacher's teaching, students passive learning, participation is low, the effect is poor, ability cannot be improved. Now it's teaching, learning, learning, and actively participating. In order to analyze and compare the effect of curriculum reform, the main observation points before and after the reform are analyzed and compared, as shown in Table 3. Through the analysis, we can also see that after the reform, we pay more attention to the improvement of students' learning ability and the improvement of their autonomous learning ability.

Table 3 Effect Analysis of curriculum reform

\begin{tabular}{|c|c|c|}
\hline compare & Traditional teaching & Curriculum reform teaching \\
\hline $\begin{array}{c}\text { instructional } \\
\text { objective }\end{array}$ & $\begin{array}{c}\text { Knowledge of environmental } \\
\text { protection }\end{array}$ & $\begin{array}{c}\text { Environmental awareness and } \\
\text { environmental protection capability }\end{array}$ \\
\hline $\begin{array}{c}\text { Content of } \\
\text { courses }\end{array}$ & Knowledge points listed & $\begin{array}{c}\text { Taking case as the main line and } \\
\text { teaching through }\end{array}$ \\
\hline $\begin{array}{c}\text { teaching } \\
\text { model }\end{array}$ & Spoon feeding Teaching & $\begin{array}{c}\text { Network platform, case, real } \\
\text { enterprise }\end{array}$ \\
\hline Teacher & lecture & Design case \\
\hline Student & Listen to class & Analysis case \\
\hline $\begin{array}{c}\text { Examination } \\
\text { results }\end{array}$ & test paper & Process oriented \\
\hline $\begin{array}{c}\text { teaching } \\
\text { effectiveness }\end{array}$ & $\begin{array}{c}\text { Knowledge and practical } \\
\text { significance }\end{array}$ & $\begin{array}{c}\text { Enhance ability and foster } \\
\text { environmental awareness }\end{array}$ \\
\hline
\end{tabular}

\section{Conclusion}

The teaching of "Introduction to Environmental Protection" has been reformed and implemented by the students for three years. The students have mastered the basic knowledge of the introduction to environmental protection, cultivated their awareness of environmental protection, and laid a solid foundation for going to work. Of course, the curriculum reform is an endless process, we need to continue to adapt to the needs of social development.

\section{Acknowledgements}

Zibo Science and Technology Development Plan Project (2014 kj010175); SHANDONG VOCATIONAL COLLEGE OF LIGHT INDUSTRY Project "Applied Chemical Technology Specialty Chemical Analysis Technology Curriculum Reform" (2017JY11).

\section{References}

[1] Wang Xuefeng, Zhang Peng. Teaching Reform Practice of Safety and Environmental Protection Technology [J]. Science and Technology Information, 2010 (21): 343.

[2] Yin Xueying, et al. Analysis of the current situation of environmental safety education in Higher Vocational Colleges and discussion of its educational model. Higher Education Forum, 2009 (12).

[3] Zhou Xiaofei. A preliminary study on the reform of the course content and teaching method of "Introduction to Environmental Protection" (non-environmental protection major) [J].Journal of South China Tropical Agricultural University, 1999 (3): 67-69. 